\title{
Big Five Personality sebagai Prediktor Kreativitas dalam Meningkatkan Kinerja Anggota Dewan
}

\author{
Hardani Widhiastuti ${ }^{1}$ \\ Fakultas Psikologi Universitas Semarang
}

\begin{abstract}
This study aimed to analyze the influence of the Big Five Personality Factors, which consists of Neuroticism, Extraversion, Openness to Experience, Agreeableness and Conscientiousness on the Creativity, and its implications to the performance of City Council members of ' $S$ ' city within the period of 2009-2014. A total number of 36 legistators who were still active became the subjects of the research. Linear Regression Analysis of the two phases was used to analyze the collected data with SPSS 19. The results showed that for Extraversion, $t$ valued 2,340 with sig. 0.026 , for Agreeableness, $t$ valued 2.760 with sig. 0,010 and for Conscientiousness, $t$ valued 2,241 with sig. 0,033 . Thus, all the three factors had significant and positive effect on creativity. In the two-stage regression test, the value of $t$ was 2.431 with a sig. 0,020. In general, the Big Five Personality traits have made positive and significant effect on the creativity and performance of City Council members of the ' $S$ ' city.
\end{abstract}

Keywords: Big Five Personality, creativity, performance, council

Abstrak. Penelitian ini bertujuan untuk menganalisis pengaruh Big Five Personality yang terdiri dari Faktor Neuroticism, Extraversion, Openness to Experience, Agreeableness, dan Conscientiousness terhadap Kreativitas, dan implikasinya pada Kinerja anggota DPRD Kota ' $S$ ' Periode 2009-2014, dengan subjek penelitian sejumlah 36. Analisis regresi linier dua tahap digunakan untuk menganalisis data dalam penelitian ini, dengan menggunakan SPSS versi 19. Hasil uji regresi tahap satu menunjukkan bahwa tiga faktor Big Five Personality yaitu Extraversion dengan $t$ hitung sebesar 2,340 dengan sig. 0,026, Agreeableness nilai $t$ hitung sebesar 2,760 sig. 0,010 dan Conscientiousness dengan $t$ hitung sebesar 2,241 dengan sig. 0,033. Dengan demikian ketiga faktor di atas berpengaruh positif dan signifikan terhadap kreativitas. Sedangkan faktor Neuroticism, dan Openness to Experience tidak berpengaruh terhadap kreativitas. Pada uji regresi tahap dua, hasil yang didapat nilai $t$ hitung sebesar 2,431 dengan sig. 0,020. Secara keseluruhan Big Five Personality berpengaruh positif dan signifikan terhadap kreativitas dan berimplikasi pada kinerja anggota Dewan Kota 'S'.

Kata kunci: Big Five Personality, kreativitas, kinerja, anggota dewan

Tujuan organisasi akan berhasil apabila ada kebersamaan dan komitmen diantara para pemegang kendali organisasi tersebut. Negara merupakan organisasi terbesar yang dikelola dengan kompleksitas yang tinggi. Selain kepala negara, para menteri, pengelola daerah dari pro-

\footnotetext{
${ }^{1}$ Korespondensi mengenai isi artikel ini dapat dilakukan melalui: dancerdas62@yahoo.com
}

vinsi hingga kabupaten, Dewan Perwakilan Rakyat Daerah memegang peran penting sebagai pengambil kebijakan.

Dewan Perwakilan Rakyat Daerah (DPRD) merupakan bentuk lembaga perwakilan rakyat daerah (provinsi/kabupaten/kota) di Indonesia yang berkedudukan sebagai unsur penyelenggara pemerintah daerah. Kedudukan DPRD 
diatur dengan undang-undang, yaitu Undang-Undang Nomor 27 Tahun 2008. DPRD berkedudukan di setiap wilayah administrasi, yaitu (1) DPRD provinsi, berkedudukan di ibu kota provinsi. (2) DPRD kabupaten, berkedudukan di ibukota kabupaten. (3) DPRD kota, berkedudukan di kota. DPRD merupakan mitra kepala daerah dalam hal; (1) Melegislasi, berkaitan dengan pembentukan peraturan daerah, (2) Anggaran, berkaitan dengan kewenangan dalam hal anggaran daerah, dan (3) Pengawasan, memiliki kewenangan untuk mengontrol pelaksanaan perda dan peraturan lainnya serta kebijakan pemerintah daerah.

Tugas para anggota DPRD sangat kompleks, oleh sebab itu diperlukan pribadi yang tangguh, penuh dedikasi, memiliki wawasan luas, dan penuh kreativitas. Dengan tugas yang kompleks tersebut, dibutuhkan kekuatan untuk mengadapi tantangan dan hambatan pekerjaan, sehingga kinerja anggota DPRD dapat berhasil dengan baik. Hal ini sesuai dengan teori Sonnentag (2000) bahwa orientasi kinerja terkait dengan positif tidaknya suatu pekerjaan yang berkaitan dengan upaya keras tidaknya seseorang dalam mencapai tujuan. Besarnya usaha seseorang dalam hal apapun terutama dalam melakukan tugas, secara personal terkait dengan kemampuan diri saat melakukan kreativitas untuk memecahkan permasalahan kemasyarakatan yang akhirnya memberi dampak positif dalam kinerja. Kemampuan diri tersebut merupakan unsur yang terkandung dalam kepribadian.

Big Five Personality merupakan salah satu teori kepribadian yang berkembang di abad ke-20an. Teori ini memiliki lima faktor kepribadian yang masing-masing faktornya memiliki enam facet. Dengan demikian, Big Five Personality memiliki 30 unsur kepribadian yang mendasari kepribadian setiap orang. Dengan adanya kupasan terhadap kecenderungan kepribadian yang lebih unik ini, diharapkan dapat mendeteksi kreativitas para anggota Dewan dalam rangka meningkatkan kinerjanya. Freud (Pervin, 2012) menjelaskan bahwa kreativitas muncul sebagai bagian dari upaya mekanisme pertahanan diri.

Berdasarkan penelitian yang dilakukan oleh Forum Masyarakat Peduli Parlemen Indonesia (Formappi) (Tempo, 2014), menunjukkan bahwa 83,8\% anggota Dewan Perwakilan Rakyat memiliki kinerja buruk. Hal ini ditunjukkan sebanyak $61,3 \%$ mendapat nilai buruk dan 22,5 persen dinilai sangat buruk. Hasil penelitian ini hampir sama dengan pendapat Saut (2014), bahwa kinerja anggota Dewan periode 2009-2014 yang didapat dengan cara mengumpulkan data kehadiran, data risalah rapat komisi, pembahasan rancangan peraturan-peraturan yang tidak memenuhi target. Penelitian Lucius (2013) yang dikutip oleh Republika, juga menjelaskan bahwa dari 70 Program Legislasi Nasional hanya ada tujuh Undang-Undang yang dihasilkan. Dengan demikian terjadi penurunan sekitar $15,25 \%$.

Permasalahan yang sering dijumpai adalah adanya berbagai pemberitaan mengenai anggota Dewan, misalnya tidak patuh pada peraturan yang telah ditetapkan, banyak anggota DPRD yang absen, banyak melakukan tindakan tidak terpuji, seperti penyelewengan anggaran oleh anggota DPRD Sragen (Bramantyo, 2013), anggota DPRD Wonosobo yang terima uang proyek dari korban penyekapan Bekasi (Amelia, 2013). Di sisi lain, anggota DPRD juga menghasilkan hal yang positif, misalnya menghasilkan sembilan Perda di Bombana, Sulawesi Tenggara (Ardian, 2014). Walaupun pemberitaan tidak se- 
rempak dan tidak semua anggota Dewan berperilaku seperti yang diberitakan, namun memberi dampak yang cukup berarti dalam memandang turunnya penilaian terhadap kinerja anggota Dewan.

Penelitian ini bertujuan untuk menganalisis Pengaruh Big Five Personality terhadap kreativitas, dan menganalisis pengaruh kreativitas terhadap kinerja anggota Dewan melalui deteksi kepribadian, dalam hal ini Big Five personality. Penelitian ini dilakukan sebagai upaya meningkatkan kinerja anggota DPRD Kota 'S'. Manfaat hasil penelitian ini adalah, selain untuk pengembangan ilmu Psikologi Industri dan Organisasi juga untuk mendapatkan jalan keluar atau masukan kepada calon maupun anggota Dewan mengenai faktor kepribadian Big Five Personality yang dapat meningkatkan kinerja melalui pengembangan Kreativitas. Kebaruan dari penelitian ini, adalah untuk menelaah kinerja anggota Dewan kaitannya dengan kreativitas melalui deteksi kepribadian.

\section{Kinerja}

Kinerja berkaitan erat dengan pola dan perencanaan suatu organisasi atau perusahaan. Dalam pelaksanaan seharihari, kinerja dapat menggambarkan adanya upaya penyelesaian suatu usaha seseorang. Dengan upaya dan kreativitas tersebut secara tidak langsung akan tercapai target tugas yang diharapkan. Kinerja tinggi merupakan gambaran lebih pada perkembangan hasil tujuan apabila dibandingkan dengan kinerja yang lemah. Perbedaan kinerja tinggi dan menengah tidak hanya pada pola hasil, tetapi juga pada tujuan yang mereka jalankan (Sonnentag, 2000).

Istilah kinerja menurut Ruky (2002) lebih pada suatu prestasi seseorang yang telah dicapai sesuai dengan informasi yang tercatat dalam agenda perusahaan atau organisasi,tentang hasil yang dicapai dalam rentang waktu yang telah ditentukan. Kinerja dapat diartikan dengan outcome atau hasil sebuah pekerjaan atas peran serta karyawan dalam suatu perusahaan atau organisasi. Dengan demikian, kinerja lebih pada capaian tugas yang terukur pada kurun waktu yang ditentukan, yang terdiri dari produktivitas kerja, komitmen, loyalitas, sikap dan perilaku, serta usaha pengembangan diri.

Di sisi lain, kinerja di perusahaan maupun organisasi harus melalui tahap penilaian dalam rangka melihat capaian atau hasil kerja seseorang karyawan dalam menyelesaikan pekerjaannya. Penilaian atas kinerja tersebut perlu dilakukan secara efektif dan berkala agar mendapatkan hasil instrumen umum untuk ukuran kinerja dalam memberi istimasi modal kinerja (Dunnette, Marvin, \& Leaetta, 1998).

Beberapa penelitian memperlihatkan hasil bahwa kinerja yang dilakukan oleh karyawan dengan sudut pandang penilaian dimensi individual, waktu, dan perbedaan situasi silang dalam pekerjaannya dapat saling memengaruhi. Apabila penelitian tentang distribusi kinerja secara individu hasilnya akurat, dapat disimpulkan bahwa antara teori dan hasil tidak banyak perbedaan. Dengan demikian, secara teori diduga hasil penelitian ini tidak banyak perbedaan (Yoo, 2002, Barrick \& Mount, 1991, dan Salgado, 1997)

Greer, 1995; Kreitner \& Angelo, 2001; Ivancevich, 2001; dan Simamora, 2005, sepakat bahwa kinerja yang efektif dapat menunjang implementasi strategis bisnis. Apabila di antara karyawan memahami dimensi-dimensi yang dievaluasi dan memahami manfaat dari aspek-aspek yang dinilai dari pekerjaannya, bahwa mereka 
memandang secara fair dan valid penilaian kinerja yang telah dilakukan.

Teori tentang kinerja yang disampaikan oleh tokoh-tokoh tersebut pada umumnya lebih menekankan pada keterkaitan antara kinerja dan unsur kepribadian. Kinerja merupakan salah satu gambaran kemampuan seorang karyawan mengenai kualitas dan kuantitas yang dimiliki. Tanggung jawab, beban kerja, strategi pengerjaan serta komitmen, merupakan unsur dari kecenderungan kepribadian termasuk kemampuan kecerdasan karyawan. Dengan demikian, karyawan merasa dihargai dan dihormati saat menghadapi penilaian kinerja karena karyawan sudah memahami dimensi maupun aspek-aspek apa saya dari kinerja yang akan dinilai. Penilaian kinerja diciptakan oleh pihak manajemen dalam upaya menciptakan pekerjaan yang efektif. Satu hal yang juga dibutuhkan agar penilaian kinerja tersebut berhasil adalah adanya peran komunikasi (Dessler, 1994).

Sharpley (1998), dalam kaitan antara kinerja dengan posisi tempat kerja karyawan, mengemukakan ada enam hal yang perlu diperhatikan, yaitu: (1) Proses seleksi pribadi, yang berkaitan dengan faktor kepribadian dan kemampuan. (2) Kualifikasi dan persyaratan pelatihan untuk berbagai profesi. (3) Norma dasar kelompok (kandidat, pelajar atau kelompok profesional). (4) Skor pemikiran kritik dan karakteristik kepribadian yang merupakan faktor risiko. (5) Perbedaan antara dua individu sebagai potensial terbaik dibandingkan dengan kelompok lain, dan

(6) Persepsi individu terhadap keseluruhan dan ide-ide tentang konstitusi perilaku yang memberikan dampak pada kinerja profesional dan pekerjaan manajerial.

Faktor-faktor yang merupakan komponen penentu kinerja menurut Gatewood (2001) dibagi menjadi tiga tipe kriteria yang dapat mengakibatkan perubahan kinerja pada waktu tertentu, yaitu (1) Konsistensi kinerja, kriteria ini terdiri dari faktor-faktor perbedaan individu. (2) Konsistensi evaluasi perubahan yang disebabkan oleh konteks seseorang terhadap organisasi seperti tujuan kerja dan desain pekerjaan, dan (3) Reliabilitas pengukuran, dalam hal ini sangat tergantung pada tenik pengukuran yang dipakai pada waktu dan tempat yang berbeda.

Kreitner dan Angelo (2001) mengemukakan bahwa komponen yang mempengaruhi penilaian kinerja adalah gaji, hasil kerja, dan identifikasi individu (keputusan, terminasi personel). Aspek-aspek kinerja menurut Komaki dkk. (2000) dipergunakan dalam penelitiannya dengan judul "A Rich and Rigorous Examination of Applied Behavior Analysis Research in The World of Work", adalah sebagai berikut: (1) produksi, (2) ketelitian akan waktu, (3) keamanan, (4) perhatian ke pelanggan ataupun klien, (5) pelayanan pelanggan, (6) laporan hasil, (7) supervise, (8) hasil setoran, dan (9) penjual. Penelitian tersebut mendasarkan pada analisis pendekatan terapan perilaku yang berfungsi untuk mengetahui harapan kinerja, khususnya hubungan perilaku dan konsekuennya, dan kesempatan konsekuen untuk mengambil tindakan, konsekuen berpikir cermat sebagai suatu kesatuan yang bersifat motivasional dalam kaitannya dengan kinerja secara keseluruhan.

Simamora (2005) mengutarakan pendapat yang berbeda, menurutnya berhasiltidaknya kinerja seseorang tidak selamanya ditentukan oleh dimensi-dimensi kinerja. Supaya organisasi berlaku secara optimal, ada tiga dimensi yang berkaitan dengan kinerja seseorang, yaitu: (1) Memikat dan menahan orang-orang dalam organisasi, dapat diartikan bahwa organisasi harus meminimalkan perputaran 
karyawan, ketidakhadiran, dan keterlambatan, (2) Menyelesaikan tugas yang terandalkan, organisasi harus mempunyai patokan dalam hal tolok ukur minimal kuantitas maupun kualitas tentang capaian kinerja, dan (3) Mempunyai perilaku inovatif dan spontan, dalam hal ini perlu mempertimbangkan kerja sama, munculnya gagasan-gagasan konstruktif dan kreatif, pelatihan-pelatihan yang mendukung dan sikap-sikap baik terhadap diri sendiri maupun pelanggan serta masyarakat umum.

Faktor-faktor yang memengaruhi kinerja, antara lain adalah faktor kepribadian. Hal ini sesuaidengan pendapat Baron dan Jerald (2000) bahwa kepribadian merupakan salah satu faktor penting yang menunjang keberhasilan kinerja, khususnya berkaitan dengan kepercayaan diri untuk ditunjukkan dalam keberhasilan menyelesaikan tugas yang spesifik, karena di dalamnya terdapat kepentingan, kekuatan, dan generalisasi. Adapun faktor-faktor lain yang memengaruhi kinerja adalah kreativitas seperti yang disampaikan dalan penelitian Supriadi (2013), bahwa faktor kemampuan dalam kepribadian secara umum, termasuk intelektual dan kreativitas. Faktor kepribadian juga memengaruhi kinerja seseorang. Hal ini sesuai dengan penelitian Sugiyanto (2003) bahwa kepribadian tidak secara langsung memengaruhi kinerja, akan tetapi melalui motivasi kerja.

Penilaian kinerja secara efektif, harus dilakukan untuk mendapatkan hasil instrumen untuk tingkatan kinerja tertentu dalam rangka memberi istimasi modal kinerja (Dunnette \& Hogh, 1998). Setiap hasil, dipersepsikan berbeda oleh individu yang berbeda. Hal ini dipengaruhi oleh faktor lain dalam kehidupannya. Selain itu perilaku juga bisa diasosiasikan dengan pemikiran individu tentang kemungkinan keberhasilan dalam kerja. Harapan ini tergantung persepsi individu tentang bagaimana dapat berperilaku dan kemungkinan sukses akibat dari perilaku.

Staw (1991) berpendapat bahwa ada tiga konsep penting kaitan antara perilaku dengan kinerja adalah: (1) Individu percaya bahwa perilaku akan mengakibatkan hasil. (2) Individu percaya bahwa hasil merupakan nilai positif individu. (3) Individu percaya bahwa ia dapat membentuk hasrat atau usaha. Berdasarkan teori-teori kinerja Staw tersebut dapat disimpulkan bahwa kinerja yang efektif dapat menunjang implementasi strategis bisnis apabila karyawan memahami dimensi-dimensi yang dievaluasi dan memahami relevansi aspek- aspek yang dinilai dari jabatannya. Kinerja terdiri atas kinerja perilaku dengan orientasi pelayanan yang meliputi aspek (1) mendengarkan permasalahan dan permohonan pelanggan, (2) membuat suatu tugas ekstra dalam rangka menolong pelanggan, (3) mengantisipasi kebutuhan pelanggan dan kecepatan merespon, akurat, dan menyenangkan, (4) menindaklanjuti pelanggan-pelanggan, (5)berempati dengan pelanggan ketika masalah terjadi, dan kinerja berupa hasil kerja dengan komponennya antara lain gaji, hasil kerja, dengan aspek-aspeknya antara lain laporan hasil, hasil setoran, dan pelayanan pelanggan. Teori Staw ini dapat diasumsikan bahwa pelayanan yang diberikan bukan saja untuk kepentingan konsumen tetapai pelayanan terhadap masyarakat luas, sebab anggota Dewan selanjutnya akan bertanggung jawab untuk melayani masyarakat luas dan dalam mengupayakan kemaslahatan orang banyak.

\section{Big Five Personality}

Teori kepribadian yang berkembang saat ini adalah teori kepribadian yang lebih detil yang disebut dengan Big Five 
Personality. Model Big Five Personality atau Model Lima Besar Kepribadian dibangun dengan pendekatan yang lebih sederhana. Walaupun teori Big Five Personality terlihat begitu kompleks dibanding dengan teori lain sebelumnya, beberapa pendekatan yang dilakukan dalam penelitian-penelitian lebih sederhana. Prosedur yang dipergunakan oleh para peneliti, yaitu mencoba menemukan unsur mendasar dari kepribadian dengan menganalisis kata-kata dalam penyusunan aitem skala yang dipergunakan oleh subjek peneliti. Big Five Personality memiliki reliabilitas dan validitas yang relatif stabil, hingga seseorang menginjak dewasa (Pervin, Cervone, \& Oliver, 2012).

Pendekatan teori kepribadian sering dipergunakan dalam rangka mencari solusi mengenai kesulitan-kesulitan yang bersifat personal. Contohnya adalah penelitian Freud tentang introspeksi diri, penelitian Jung tentang kemampuan melakukan visi dan ketertarikan terhadap pengalaman, Rogers meneliti dengan pendekatan optimistik untuk menghadapi tantangan ke depan dan Erikson menemukan tentang identitas unik pada diri (Monte \& Robert, 2003).

Model perbedaan individu akan mudah ditunjukkan dengan beberapa level yang disebut dengan "Lima Besar" dimensi. Goldberg (Pervin, 2000) menyatakan penemuan penelitiannya mengenai dimensi bahwa "Besar" artinya ada beberapa sub-sub faktor yang lebih spesifik pada sifat seseorang. "Lima Besar" hampir tidak dapat dijangkau dan abstrak dalam hierarki kepribadian. Eysenck menyebut dengan "Faktor-faktor super". Meskipun berbeda dalam terminologi untuk "Lima Besar", faktor yang dimaksud, antara lain Neuroticism $(\mathrm{N})$ atau Neuroticism, Extraversion (E) atau Ekstraversi, Opennes to experience (O) atau Keterbukaan atas pengalaman,
Agreeableness (A) atau Kesepakatan, dan Conscientiousness (C) atau Ketelitian.

John (1990) membuat singkatan atas kelima Faktor Kepribadian tersebut dengan OCEAN, Sedangkan Digman dan Hogan (1996) menyebutkan dengan istilah Neuroticism (N) mencakup perasaan-perasaan negatif, cemas, sedih, mudah tersentuh, nervous. Faktor Keterbukaan atas pengalaman $(\mathrm{O})$ meliputi keterbukaan, kedalaman dan mental individual yang kompleks dan pengalaman hidup. Ekstraversi (E) dan faktor Kesepakatan (A) termasuk interpersonal bahwa seseorang dapat bekerjasama dan bergaul dengan orang lain. Terakhir adalah yang disebut dengan faktor Ketelitian (C), menyangkut tugas dan capaian serta kontrol yang merupakan persyaratan sosial.

Lima Faktor Kepribadian ini didesain untuk melihat karakter kepribadian seseorang yang paling penting dalam hidupnya. Hipotesis leksikal yang paling mendasar adalah bahwa perbedaan individu dalam transaksi manusia akan dikode sebagai terminologi tunggal atau semua dari bahasa di dunia (Goldberg, 1990). Variasi dari perbedaan individu lebih pada suatu gabungan dari facet-facet tersebut.

Goldberg (Pervin, 2000) mengilustrasikan arti dari faktor-faktor tersebut. Kepekaan emosi yang merupakan bagian dari Neuroticism (N) dengan sisi lain dari perasaan negatif termasuk kecemasan, sedih, mudah tersinggung, dan gugup. Faktor Keterbukaan atas pengalaman $(\mathrm{O})$ digambarkan dengan keluasan, kedalaman dan kompleksitas dari mental individu dalam pengalaman hidup. Faktor Ekstraversi (E) dan faktor Kesepakatan (A), kedua sifat tersebut lebih bersifat interpersonal, yang berarti perbuatan seseorang dalam kaitannya dengan orang lain. Faktor ketelitian (C) telah dijelaskan di awal, lebih berkaitan dengan tugas dan perilaku sebagai 
tujuan akhir dan pengendalian diri sebagai faktor sosial.

\section{Pengaruh Big Five Personality terhadap Kinerja}

Penelitian Hogan (1996) menghasilkan rangkaian yang lebih tinggi tingkatannya yang menggambarkan kepribadian secara unik sebagai instrumen yang terstandar, sehingga dapat memprediksi hubungan dengan pendekatan kinerja dan beberapa kasus yang mengutamakan pada kemampuan kognisi, khususnya dalam penelitian kepribadian yang berhubungan dengan model Lima Faktor Keribadian (Big Five Personality) yang sering disebut dengan "Lima Besar".

Barrick dan Mount (1991) meneliti tentang kaitan Lima Faktor Kepribadian dengan kinerja, dalam hal ini menggunakan korelasi terhadap Lima Faktor Kepribadian sebagai prediktor dari kinerja dan kecakapan dalam pelatihan pada lima level pekerjaan. Hasilnya adalah faktor Ektraversi berpengaruh terhadap kinerja untuk level pekerjaan manajer, faktor Kesepakatan berpengaruh terhadap kinerja untuk level pekerjaan manajer dan polisi, sedangkan faktor Ketelitian berpengaruh terhadap Kinerja untuk semua level pekerjaan, faktor Neuroticism berpengaruh terhadap Kinerja polisi serta faktor Keterbukaan atas Pengalaman dan faktor Ekstraversi berpengaruh terhadap Kinerja untuk level pekerjaan kecakapan dalam memberikan pelatihan.

Hasil penelitian lain menunjukkan bahwa tingkatan yang paling tinggi pada faktor Ketelitian dan Stabilitas emosi, diasosiasikan dengan tingkatan yang tinggi pada kinerja hubungannya dengan kelompok jabatan dan seluruh pengukuran kinerja (Salgado, 1997). Pada penelitian tersebut terdapat perbedaan bahwa kemungkinan setiap individu dengan tingkat
Ketelitian (C) yang tinggi akan jarang melakukan absen dari pekerjaannya dibanding dengan yang rendah tingkat ketelitiannya, sedangkan seseorang yang memiliki kemampuan Ekstraversi (E) rendah, memiliki kecenderungan untuk kehilangan pekerjaan.

Berbeda dengan penelitian lain, penelitian yang dilakukan oleh Barrick, Piotrowski, dan Stewart, (2002) membuktikan bahwa dari kelima Faktor Kepribadian tersebut, hanya dua faktor yang berhubungan signifikan dengan kinerja, yaitu Ketelitian (C) dan Ekstraversi (E). Namun penelitian ini dilakukan pada level manajer. Sementara itu penelitian yang dilakukan oleh Dunn, Mount, Barrick, dan Ones (1995), daitemukan bahwa model Lima Besar Kepribadian berisi kemajuan dalam memahami kepribadian dalam kaitannya dengan kemungkinan kriteria pekerjaan. Manajer sebagai objek penelitian, bersama dengan supervisor melakukan seleksi terhadap pelamar dengan enam tipe tugas. Hal ini dilakukan dalam rangka mengevaluasi potensi kinerja dan integritas pelamar dari deskripsi kepribadian yang berbasis Lima Faktor Kepribadian dan General Mental Ability (GMA).

\section{Pengembangan Kreativitas}

Kreativitas sangat dibutuhkan untuk mendukung pekerjaan atau tugas-tugas tertentu, misalnya pekerjaan dibidang iklan, pemasar, manajer, anggota dewan. Kreativitas adalah suatu proses mental yang melibatkan munculnya gagasan atau konsep baru, atau hubungan baru antara gagasan dan konsep yang sudah ada. Berdasarkan sudut pandang keilmuan tersebut, hasil dari pemikiran kreatif (kadang disebut pemikiran divergen), biasanya dianggap memiliki keaslian dan kepantasan. Sebagai alternatif, konsepsi 
sehari-hari dari kreativitas adalah tindakan membuat sesuatu yang baru.

Dijelaskan dalam beberapa teori bahwa kreativitas yang muncul disebabkan seseorang harus berhadapan dengan permasalahan. Semakin banyak permasalahan yang dihadapi semakin tinggi tuntutan. Hal ini akan memunculkan ideide maupun kreativitas dalam penanganan masalah maupun pencegahannya. Mekanisme pertahanan diri yang menghasilkan pemikiran dan ide-ide baru tersebut merupakan produk kreatif seseorang, yang kadang disadari justru merupakan penyebab utama munculnya kreativitas (Pervin, 2012).

Carl Jung (Pervin, 2012) mengemukakan bahwa peran dari ketidaksadaran pada ambang atas yang dialami seseorang sangat berharga, khususnya berkaitan dengan kreativitas seseorang. Alam bawah sadar tersebut terbentuk di masa lalu. Selama proses berlangsung, biasanya akan muncul ide-ide, temuan-temuan, teoriteori, juga karya-karya baru. Proses inilah yang menyebabkan terbentuknya eksistensi manusia dalam hal kreativitas.

\section{Proses Kreatif}

Kreativitas seseorang selalu menjadi sorotan dalam berbagai sudut pandang, mengingat kreatif merupakan unsur utama seseorang melakukan suatu aksi. Dalam bidang apapun, kreativitas dapat menentukan seseorang untuk melakukan suatu aksi yang bervariasi, sehingga permasalahan yang dihadapi dapat terselesaikan dengan adanya kreativitas tersebut. Di satu sisi, kreativitas harus melewati suatu proses panjang dan pembelajaran, sehingga walaupun melewati tahapan tertentu yang relatif sama, jangkauan dan hasilnya akan berbeda satu dengan lain orang.
Wallace (2010) adalah salah satu tokoh penemu teori tentang proses kreatif. Dalam bukunya "The Art of Thought" dijelaskan bahwa proses kreatif meliputi empat tahap (1) Tahap Persiapan, yaitu seseorang mempersiapkan diri untuk memecahkan masalah dengan mengumpulkan data/informasi, mempelajari pola berpikir dari orang lain, bertanya kepada orang lain, (2) Tahap Inkubasi, pada tahap ini seseorang melakukan penghentian proses pengumpulan informasi, dalam arti individu melepaskan diri untuk sementara masalah yang dialami. Ia tidak memikirkan masalah tersebut secara sadar, tetapi “mengeramkannya' dalam alam pra sadar, (3) Tahap Iluminasi, tahap ini merupakan tahap timbulnya "insight" atau "Aha Erlebnis", yaitu saat timbulnya inspirasi atau gagasan baru, dan (4) Tahap Verifikasi, tahap ini merupakan tahap pengujian ide atau kreasi baru terhadap realitas. Pada tahap ini diperlukan pemikiran kritis dan konvergen, karena proses divergensi (pemikiran kreatif) harus diikuti proses konvergensi (pemikiran kritis).

Menurut Sternberg (1999), kreativitas seseorang muncul dari tiga atribut psikologis yang umum kita jumpai, antara lain, inteligensi atau gaya kognitif, kepribadian dan motivasi. Atribut psikologis tersebut secara langsung akan membentuk diantaranya adalah aspek dari Kreativitas, antara lain dalam bentuk (1) Aspek pribadi, aspek ini muncul dengan adanya interaksi yang dianggap unik dalam lingkungannya. Berdasarkan lingkuang itulah, seseorang mengembangkan kreativitas. (2) Aspek pendorong, aspek ini muncul sebagai pendorong kreativitas untuk mewujudkan upaya mendorong sisi internal dan eksternal dari lingkungan, (3) Aspek proses. Aspek ini merupakan aspek wujud dari proses dan pengamatan adanya masalah, sehingga berdampak muncul dugaan 
mengenai kurangnya data permasalahan, menilai serta menguji dugaan sementara atau hipotesis yang didapat, dan (4) Aspek produk, aspek ini lebih menekankan pada apa yang dihasilkan dari aspek proses di atas. Hal-hal yang menjadi hasil kreativitas. Hasilnya antara lain sesuatu yang baru, orisinil, dan bermakna.

Dengan adanya aspek kreativitas tersebut, para tokoh penemu teori kreativitas menyimpulkan bahwa kreativitas yang dimiliki oleh setiap orang prinsipnya adalah berpokok pada empat hal tersebut, yaitu aspek pribadi, pendorong, proses, dan aspek produk. Namun dari sisi kualitas dan kuantitas akan berbeda satu dengan yang lain, tergantung kemampuan.

Dengan paparan teori tersebut, kaitan masing-masing teori dapat disimpulkan dalam sebuah gambar kerangka penelitian seperti pada Gambar 1.

Berdasarkan Kerangka Penelitian yang telah dibangun, dapat dihasilkan enam hipotesis, yaitu (H1) Ada pengaruh positif Neuroticism terhadap Kreativitas. (H2) Ada pengaruh positif Exstraversion terhadap Kreativitas.(H3) Ada pengaruh positif antara Openness to experience terhadap Kreativitas. (H4) Ada pengaruh positif Agreeableness terhadap Kreativitas. (H5) Ada pengaruh positif Conscientiousness terhadap Kreativitas, dan (H6) Ada pengaruh positif Big Five Personality terhadap kreativitas yang berimplikasi terhadap Kinerja Dewan.

\section{Metode}

Penelitian ini dilakukan dengan menggunakan metode penelitian kuantitatif. Teknik analisis data menggunakan Regresi Linier dua tahap atau Two Stage Least Square (2SLS) dengan SPSS 19. Tahap pertama melakukan regresi faktor Big Five Personality terhadap Kreativitas. Tahap kedua melakukan regresi nilai prediksi regresi tahap pertama dengan Kinerja anggota DPRD, yang dapat dituliskan dalam model matematis sebagai berikut:

Tahap I

$$
\begin{aligned}
Y_{1}= & \beta_{0}+\beta_{1} X 1+\beta_{2} X 2+\beta_{3} X 3+\beta_{4} X 4+ \\
& \beta_{5} X 5+\varepsilon
\end{aligned}
$$

Tahap II

$$
Y_{2}=\alpha_{0}+\alpha_{1} \hat{Y}+\varepsilon
$$

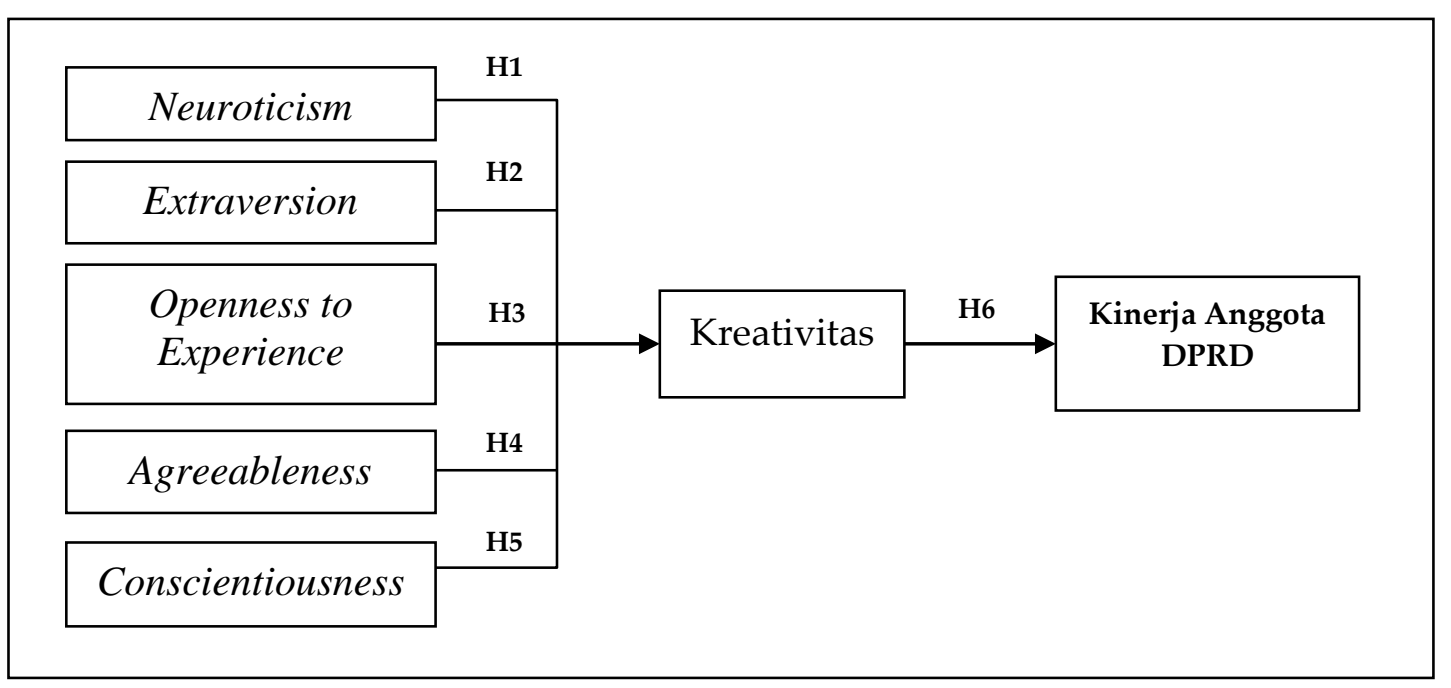

Gambar 1. Kerangka Penelitian 
Keterangan:

$$
\begin{array}{ll}
\mathrm{Y}_{1} & =\text { Kreativitas } \\
\mathrm{Y}_{2} & =\text { Kinerja Dewan } \\
\hat{\mathrm{Y}} & =\text { Nilai prediksi regresi tahap I } \\
\beta_{0} & =\text { Konstanta } \\
\beta_{1-5} & =\text { Koefisien regresi } \\
\mathrm{X} 1 & =\text { Neuroticism } \\
\mathrm{X} 2 & =\text { Extraversion } \\
\mathrm{X} 3 & =\text { Openness to Experience } \\
\mathrm{X} 4 & =\text { Agreeableness, } \\
\mathrm{X} 5 & =\text { Conscientiousness, } \\
\varepsilon & =\text { Error }
\end{array}
$$

Penelitian ini menganalisis variabelvariabel Big Five Personality, Kreativitas, dan Kinerja. Sedangkan alat ukur yang dipergunakan untuk mengumpulkan data penelitian adalah skala yang diukur dengan skala semantik 10 poin dimana poin 1 untuk penilian sangat jelek sekali sampai dengan poin 10 untuk penilaian sangat baik sekali (Ferdinand, 2011).

Kinerja anggota Dewan, diungkap dengan menggunakan skala kinerja yang terdiri dari aspek presensi kehadiran, pelayanan masyarakat dan capaian target (termasuk Perda yang telah dihasilkan dan anggota dewan siapa saja yang terlibat). Aspek kinerja didapat dari teori Staw (1991) dan Simamora (2005) yang disesuaikan dengan karakteristik kreativitas pekerjaan anggota Dewan. Sedangkan skala untuk mengungkap kepribadian yang terkait variabel Big Five Personality adalah sesuai dengan teori Goldberg (Pervin, 2000), yaitu faktor Neuroticism yang terdiri dari faset cemas, ketelitian diri, depresi, cepat tersinggung, perasa, mudah marah, faktor Extraversion yang terdiri dari facet dapat berbaur dalam kelompok, suka beraktivitas, memiliki pertahanan, senang berekplorasi, memiliki emosi stabil, memiliki kehangatan, faktor Openness to Experience yang terdiri dari facet senang berkhayal, keindahan, memiliki perasaan, ide-ide, aksi-aksi, nilai-nilai, faktor Agreeableness yang terdiri dari ketulusan, kepercayaan, mementingkan orang lain, rendah hati, sebagai tempat berlabuh, pemaaf, dan faktor Conscientiousness yang terdiri dari facet memiliki disiplin diri, penurut, memiliki kemampun mengatur, penuh pertimbangan, berjuang untuk sampai ke tujuan.

Di sisi lain, kreativitas merupakan kemampuan individu untuk menciptakan sesuatu yang baru. Biasanya seorang yang kreatif memiliki sifat yang mandiri. Kreativitas anggota Dewan diungkap menggunakan skala sesuai aspek kreativitas (Sternberg, 1999) yaitu (1) pribadi, merupakan interaksi yang dianggap unik dari lingkungan,(2) pendorong, dalam hal ini mendorong sistem yang ada di internal dan eksternal lingkungan, (3) proses, sebagai wujud pengamatan seseorang terhadap permasalahan, dan (4) produk, merupakan hasil dari proses di atas.

Subjek penelitian sebanyak 36 orang, jumlah anggota Dewan Kota 'S' sebanyak 50 orang, walaupun jumlah subjek terbatas, Ferdinand (2011) berpendapat bahwa sampel penelitian sebaiknya lebih besar dari 30 dan kurang dari 500. Jumlah tersebut sudah memadai bagi suatu penelitian. Skala dibagikan ke seluruh anggota DPRD Kota 'S' dalam empat gelombang sesuai dengan agenda atau jadwal Sidang Komisi pada bulan September dan Oktober 2013 namun hanya 36 orang (72\%) yang mengembalikan skala penelitian.

Uji Validitas dilakukan dengan membandingkan nilai $r$-hitung dengan $r$-tabel. Uji normalitas data penelitian tahap pertama dan tahap kedua menggunakan uji one sample Kolmogrorov-Smirnov. Sedangkan uji reliabilitas menggunakan Cronbach Alpha (Nunuly dalam Ghozali, 2011). Pengujian heteroskedastisitas dilakukan dengan melihat scatterplot antara 
Standardized Predicted Value (ZPRED) dengan Studentized Residual (SRESID), dan uji multikolinearitas.

\section{H a s i 1}

Teknik analisis Big Five Personality sebagai prediktor kreativitas dalam meningkatkan kinerja anggota Dewan dengan menggunakan analisis regresi linier dua tahap atau Two Stage Least Square (2SLS) dengan bantuan software SPSS versi 19. Perlu dijelaskan bahwa data yang dipergunakan dalam analisis statistik penelitian ini adalah skor murni ( $t$-score) yang merupakan hasil konversi dari raw score. Hal ini bertujuan untuk mempermudah membandingkan antara skor hasil yang didapat dari pengukuran variabelvariabel yang diteliti serta dalam rangka menghindari kesalahan pengukuran.

Sebelum menganalisis data terlebih dahulu dilakukan uji validitas yang dilakukan dengan membandingkan nilai $r$ hitung dengan $r$-tabel. Variabel Big Five Personality, Kreativitas dan kinerja memberikan nilai $r$-hitung antara 0,279-0,8 lebih besar dari $r$-tabel ( $n=36$ dan taraf nyata $5 \%$ ) sebesar 0,275 sehingga skor aitem pada penelitian ini dinyatakan valid. Sementara itu uji reliabiltas terhadap variabel yang digunakan dalam penelitian ini memberikan nilai Cronbach Alpha antara 0,74-0,87 yang lebih besar dari 0,6 sehingga data dinyatakan reliabel (Nunuly dalam Ghozali, 2011).

Uji normalitas data penelitian tahap pertama dan tahap kedua menggunakan uji One Sample Kolmogorov-Smirnov dengan hasil regresi tahap I menghasilkan nilai asymp. Sig.0,630 dan regresi tahap II nilai asymp. Sig. 0,360 lebih tinggi dari $\alpha$ $=0,05$ sehingga data berdistribusi normal. Pengujian heteroskedastisitas dilakukan dengan melihat Scatterplot antara Stan- dardized Predicted Value (ZPRED) dengan Studentized Residual (SRESID). Ada tidaknya pola tertentu pada grafik scatterplot antara SRESID dan ZPRED dimana sumbu $Y$ adalah $Y$ yang telah diprediksi dan sumbu $X$ adalah residual ( $Y$ prediksi - $Y$ sesungguhnya). Jika ada pola tertentu, seperti titik-titik yang ada membentuk suatu pola tertentu yang teratur (bergelombang, melebar kemudian menyempit), maka terjadi Heteroskedastisitas dan juga sebaliknya (Ghozali, 2011). Hasil pengujian heteroskedastisitas dengan scatterplot yang ditunjukkan pada Gambar 2 dapat diketahui bahwa titik-titik tidak membentuk pola yang jelas, dan titik-titik menyebar di atas dan di bawah angka 0 pada sumbu Y. Jadi dapat disimpulkan bahwa tidak terjadi masalah heteroskedastisitas dalam model penelitian ini, seperti pada Gambar 2.

Berdasarkan Tabel 1 dapat dijelaskan bahwa nilai tolerance lebih besar dari 0,10 dan nilai $\mathrm{VIF}<10$ untuk semua variabel independen yang digunakan. Hal ini mengindikasikan bahwa penelitian ini terbebas dari masalah multikolinearitas. Sementara itu uji multikolinearitas penelitian tahap kedua tidak perlu dilakukan, karena regresi linier hanya terdapat satu variabel independen dan satu variabel dependen. Rangkuman hasil analisis regresi tahap pertama dan tahap kedua dapat dilihat pada Tabel 2 dan Tabel 3.

Berdasarkan Tabel 1 dan Tabel 2, dapat dituliskan persamaan regresinya sebagai berikut:

$$
\begin{aligned}
& \text { Kreativitas }=-8,05+0,059 \text { Neuroticism }+ \\
& \text { 0,229 Extraversion }+ \\
& \text { 0,023 Openness to Experience + } \\
& \text { 0,371 Agreeableness }+ \\
& \text { 0,382 Conscientiousness }
\end{aligned}
$$


Uji Hetero Regresi Tahap I

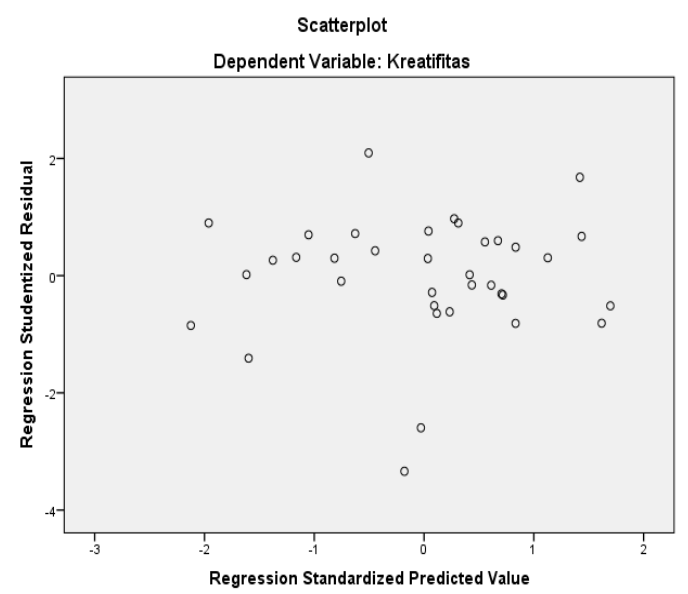

Uji Hetero Regresi Tahap II

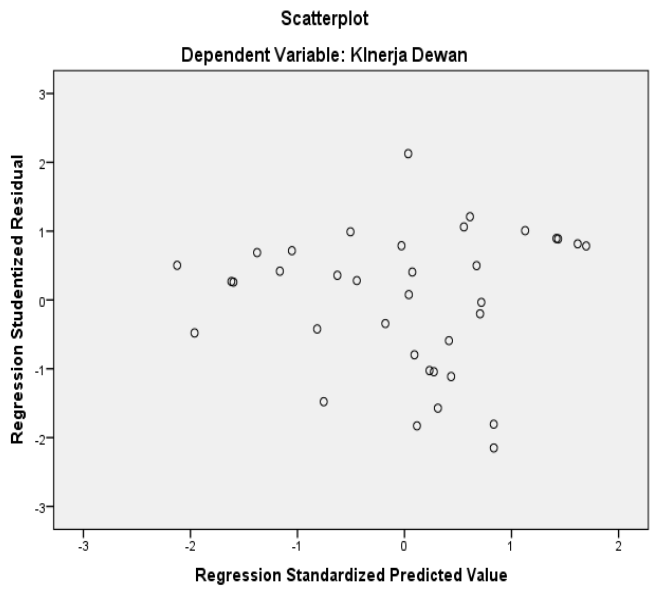

Sumber: data primer diolah, 2014

Gambar 2. Hasil Uji Hetero Regresi Tahap I \& II

Tabel 1.

Uji Multikolinieritas

\begin{tabular}{llccl}
\hline \multirow{2}{*}{ No } & \multirow{2}{*}{ Variabel Bebas } & \multicolumn{2}{c}{ Collinearity Statistics } & \multirow{2}{*}{ Keterangan } \\
\cline { 3 - 4 } & & Tolerance & VIF & \\
\hline $\mathbf{1}$ & Neuroticism & .292 & 3.428 & Bebas Multikol \\
$\mathbf{2}$ & Extraversion & .632 & 1.582 & Bebas Multikol \\
$\mathbf{3}$ & Open to Experience & .323 & 3.093 & Bebas Multikol \\
$\mathbf{4}$ & Agreeableness & .438 & 2.281 & Bebas Multikol \\
$\mathbf{5}$ & Conscientiousness & .429 & 2.331 & Bebas Multikol \\
\hline
\end{tabular}

Sumber: data primer diolah, 2014

Tabel 2

Regresi Tahap I

\begin{tabular}{lccccc}
\hline \multirow{2}{*}{ Variabel Independen } & \multicolumn{2}{c}{ Unstandardized Coefficients } & $\begin{array}{c}\text { Standardized } \\
\text { Coefficients }\end{array}$ & $\boldsymbol{t}$ & Sig. \\
\cline { 2 - 5 } & \multicolumn{1}{c}{$\boldsymbol{B}$} & Std. Error & Beta & & \\
\hline (Constant) & -8.050 & 9.631 & & -.836 & .410 \\
\hline Neuroticism & .059 & .161 & dan.063 & .364 & .718 \\
Extraversion & .229 & .098 & .273 & 2.340 & .026 \\
Open to Experience & .023 & .149 & .025 & .154 & .879 \\
Agreeableness & .371 & .134 & .387 & 2.760 & .010 \\
Conscientiousness & .382 & .170 & .317 & 2.241 & .033 \\
\hline
\end{tabular}

a. Dependen Variabel: Kreatifitas 
Persamaan regresi yang dipaparkan di atas, di dapat hasil bahwa faktor Conscientiousness $(38,2 \%)$ merupakan faktor yang lebih berpengaruh terhadap kreativitas, selanjutnya faktor Agreeableness (37,1\%) pada urutan pengaruh yang ke dua terhadap kreativitas, dan yang ke tiga adalah faktor Extraversion (22,9\%). Sedangkan faktor Neuroticism $(5,9 \%)$ dan faktor Openness to Experience (23\%) berdasarkan analisis statistik hasilnya tidak berpengaruh. Dengan demikian, pada penelitian ini seluruh aitem variabel Big Five Personality memberikan tanda yang positif.

Hasil analisis data Neuroticism memberikan nilai $t$ hitung sebesar 0,364 (positif) dengan nilai signifikansi 0,718 lebih besar dibanding tingkat signifikansi yang digunakan $\alpha=0,05$ (Tabel 2). Hal ini menunjukkan bahwa faktor Neuroticism tidak berpengaruh signifikan terhadap kreativitas. Dengan demikian hipotesis pertama (H1) yang menyatakan ada pengaruh positif dan signifikan antara Neuroticism dengan kreativitas adalah ditolak.

Variabel Exstraversion memberikan nilai $t$ hitung sebesar 2,340 (positif) dengan nilai signifikansi 0,026 lebih kecil dibanding tingkat signifikansi yang digunakan $\alpha=0,05$ (Tabel 2). Hal ini membuktikan bahwa faktor Extraversion berpengaruh signifikan terhadap kreativitas. Dengan demikian hipotesis kedua yang menyatakan ada pengaruh positif dan signifikan antara extraversion dengan Kreativitas adalah diterima.
Variabel Openness to experience dapat dilihat nilai $t$ hitung sebesar 0,154 (positif) dengan nilai signifikansi 0,879 lebih besar dibanding tingkat signifikansi yang digunakan $\alpha=0,05$ (Tabel 2). Hal ini menunjukkan bahwa faktor Openness to Experience tidak berpengaruh signifikan terhadap kreativitas.

Variabel Agreeableness dapat dilihat nilai $t$ hitung sebesar 2,760 (positif) dengan nilai signifikansi 0,010 lebih kecil dibanding tingkat signifikansi yang digunakan $\alpha=0,05$ (Tabel 2). Hal ini membuktikan bahwa faktor Agreeableness berpengaruh signifikan terhadap kreativitas. Dengan demikian hipotesis keempat yang menyatakan ada pengaruh positif dan signifikan antara Agreeableness dengan Kreativitas adalah diterima.

Variabel Conscientiousness dapat dilihat nilai $t$ hitung sebesar 2,241 (positif) dengan nilai signifikansi 0,033 lebih kecil dibanding tingkat signifikansi yang digunakan $\alpha=0,05$ (Tabel 2). Hal ini membuktikan bahwa faktor Conscientiousness berpengaruh signifikan terhadap kreativitas. Dengan demikian hipotesis keempat yang menyatakan ada pengaruh positif dan signifikan antara Conscientiousness dengan Kreativitas adalah diterima.

Untuk menguji hipotesis ke enam (H6) yang menyatakan bahwa variabel Big Five Personality berpengaruh terhadap kreativitas berimplikasi terhadap kinerja dewan dilakukan dengan regresi tahap kedua (lihat Tabel 3).

Tabel 3

Regresi Tahap II

\begin{tabular}{|c|c|c|c|c|c|}
\hline \multirow{2}{*}{ Variabel Bebas } & \multicolumn{2}{|c|}{ Unstandardized Coefficients } & \multirow{2}{*}{$\begin{array}{c}\begin{array}{c}\text { Standardized } \\
\text { Coefficients }\end{array} \\
\text { Beta } \\
\end{array}$} & \multirow[t]{2}{*}{$\mathbf{t}$} & \multirow{2}{*}{ Sig. } \\
\hline & B & Std. Error & & & \\
\hline (Constant) & 1.412 & 6.668 & & .212 & .834 \\
\hline Predicted Value Kreativitas & .216 & .089 & .385 & 2.431 & .020 \\
\hline
\end{tabular}

a. Dependent Variable: Kinerja Dewan 
Dengan demikian, hasil analisis tersebut dapat dimasukkan dalam persamaan sebagai berikut:

Kinerja Dewan $=1,412+0,216$ Kreativitas

Persamaan regresi linier diatas menunjukan bahwa variabel kreativitas memberikan nilai yang positif yang dapat diartikan seseorang yang memiliki kecenderungan Big Five Personality, maka akan semakin meningkatkan kreativitas yang berimplikasi terhadap kinerja anggota Dewan.

Variabel kreativitas memberikan nilai $t$ hitung sebesar 2,431 (positif) dengan nilai signifikansi 0,020 lebih kecil dibanding tingkat signifikansi yang digunakan $\alpha=$ 0,05 (Tabel 3). Hal ini membuktikan bahwa kreativitas berpengaruh signifikan terhadap kinerja anggota Dewan. Dengan demikian Hipotesis keenam yang menyatakan bahwa ada pengaruh positif dan signifikan antara Big Five Personality terhadap kreativitas yang berimplikasi terhadap Kinerja Dewan adalah diterima.

\section{Uji koefisien determinasi $\left(R^{2}\right)$}

Tabel 4

Uji Koefisein Determinasi Regresi Tahap I

\begin{tabular}{ccccc}
\hline Model & $\boldsymbol{R}$ & $\begin{array}{c}\boldsymbol{R} \\
\text { Square }\end{array}$ & $\begin{array}{c}\text { Adjusted } \\
\mathrm{R} \text { Square }\end{array}$ & $\begin{array}{c}\text { Std. Error of } \\
\text { the Estimate }\end{array}$ \\
\hline $\mathbf{1}$ & $.861^{\mathrm{a}}$ & .741 & .698 & 7.22011 \\
\hline
\end{tabular}

Nilai koefisien determinasi dalam regresi linear berganda pada tahap pertama ditunjukkan dengan adjusted $R^{2}$ sebesar 0,698 yang artinya 69,8\% variabel Big Five Personality yang terdiri dari faktor Neuroticism, Extraversion, Openness to Experience, Agreeableness, dan Conscientiousness mampu menjelaskan variasi dari Kreativitas. Sedangkan pada Tabel 5 yang berisi hasil uji koefisein determinasi regresi tahap kedua menunjukkan adjusted $R^{2}$ sebesar 0,123 yang artinya $12,3 \%$ variabel kreati- vitas mampu menjelaskan variabel kinerja Dewan.

Tabel 5

Uji Koefisein Determinasi Regresi Tahap II

\begin{tabular}{ccccc}
\hline Model & $R$ & $\begin{array}{c}R \\
\text { Square }\end{array}$ & $\begin{array}{c}\text { Adjusted } \\
\text { R Square }\end{array}$ & $\begin{array}{c}\text { Std. Error of } \\
\text { the Estimate }\end{array}$ \\
\hline $\mathbf{1}$ & $.385^{\mathrm{a}}$ & .148 & .123 & 5.94982 \\
\hline
\end{tabular}

a. Predictors: (Constant), Predicted Value

Kreativitas

b. Dependent Variable: KinerjaDewan

\section{Diskusi}

Hasil pengujian hipotesis menghasilkan analisis bahwa seluruh aitem variabel Big Five Personality memberikan tanda yang positif. Hal ini menunjukkan bahwa semakin seseorang memiliki kecenderungan yang terdapat pada kepribadian Big Five Personality yang terdiri dari Neuroticism, Extraversion, Openness to experience, Agreeableness, dan Conscientiousness, maka ia akan memiliki kreativitas yang tinggi yang memberi dampak pada kinerja yang lebih tinggi atau lebih baik. Hal ini senada dengan penelitian Askarian, (2013)tentang keterkaitan antara kepribadian Big Five Personality dengan kinerja. Hasil penelitian Askarian menemukan bahwa keempat faktor Big Five Personality berpengaruh terhadap kinerja kecuali Neuroticism yang bertanda negatif.

Faktor Neuroticism dalam penelitian ini tidak berpengaruh dengan kreativitas. Sehingga apabila para anggota dewan memiliki stabilitas emosi baik, dapat dengan mudah muncul kreativitas untuk mengatasi permasalahan-permasalahan yang ada. Hal ini sesuai dengan teori Pervin (2012) bahwa kreativitas dipengaruhi oleh kesadaran dan ketidaksadaran seseorang. Dalam kondisi sadar, seseorang dengan jernih akan menuangkan kreativitasnya. Namun sebaliknya, apabila seseorang dalam kondisi emosi, maka ketidak- 
sadaran menjadi penghambat kreativitas. Sehingga apabila dikaitkan dengan tugas para anggota Dewan, maka kepribadian Neuroticism tidak dapat mendukung kreativitas.

Hasil uji analisis terhadap Extraversion dengan Kreativitas adalah diterima. Hasil ini sesuai dengan teori Goldberg (Pervin, 2000) dan Costa dan McCrae (1992), bahwa Extraversion melalui facet ini sesuai dengan indikator dari tugas anggota dewan, bahwa kreativitas dibutuhkan agar memiliki kontrol terhadap emosi, supaya dapat memberi layanan kepada msyarakat luas, dan memiliki visi misi yang sama dengan dan kompak dengan kelompok komisi maupun partai yang mengusungnya.

Openness to Experience atau keterbukaan atas pengalaman, sesuai analisis data statistik tidak berpengaruh terhadap kreativitas, walau dalam facet diantaranya terdapat dorongan ide-ide, nilai-nilai. Namun satu hal yang kemungkinan adanya facet senang berkhayal dan menyukai dengan hal-hal yang indah, sehingga facet ini bertentangan dengan indikator kreativitas anggota Dewan. Hasil penelitian Parvin (2000) disampaikan bahwa Openness to Experience mempengaruhi kinerja untuk pekerjaan-pekerjaan tertentu.

Hasil analisis terhadap Agreeableness atau kesepakatan berpengaruh terhadap kreativitas. Hasil penelitian ini dikuatkan dengan penelitian Berry dkk. (2007) bahwa unsur interpersonal individu termasuk kepribadian, berhubungan dengan pekerjaan dan organisasi tempat individu bekerja. Kreativitas menjadi salah satu syarat keberhasilan kerja. Walaupun Berry dkk. (2007) tidak membahas secara khusus tentang Big Five Personality, namun secara umum unsur yang terpecah dalam facet Agreeableness antara lain dengan tulus melayani, ikhlas, dan dengan ikhlas menjalani tugas merupakan aspek kepribadian. Dengan demikian, sebaiknya para anggota Dewan memiliki kecenderungan kepribadian Agreeableness yang baik, sehingga anggota Dewan dapat dengan tulus ikut serta memecahkan masalahmasalah yang muncul di masyarakat, begitu juga dengan Conscientiousness.

Conscientiousness berpengaruh terhadap kreativitas. Dengan demikian Conscientiousness memberi dampak yang sangat berarti bagi kreativitas. Apabila dikaitkan dengan hasil pemikiran teoritis dari Wallace (2010) bahwa kreativitas muncul dengan melalui tahapan proses, yaitu persiapan, inkubasi, iluminasi, dan verifikasi, sesuai dengan facet yang ada pada faktor Conscientiousness yaitu facet "berjuang untuk sampai ke tujuan". Komitmen untuk mencapai tujuan menjadi pendorong untuk melakukan kreativitas. Intelektual menjadi salah satu facet yang optimum akan menjadikan kreativitas seseorang semakin meningkat, karena proses tersebut dapat dilalui dengan baik. Berkaitan dengan intelektual, Jauk dkk. (2013) dalam temuan penelitiannya, inteligensi yang tinggi akan mempresentasikan kondisi kreativitas yang tinggi pula. Walaupun inteligensi di sini menguji indikator potensi yang berbeda, namun peningkatan hanya pada potensi kreativitas bukan pada sumber peningkatannya.

Uji analisis pada tahap satu, Big Five Personality berpengaruh terhadap kinerja, namun pengaruh kepribadian secara langsung tidak terhadap kinerja, akan tetapi melalui variabel kreativitas. Tidak semua unsur Big Five Personality berpengaruh terhadap kreativitas, diantaranya Neuroticism dan Openness to Experience. Hal ini berbeda dengan penelitian Buchanan dkk. (1998) bahwa kelekatan kelompok kerja terkait dengan kepribadian antar anggota kelompok mempengaruhi kreativitas kelompok, 
khususnya Openness to Experience dan Conscientiousness. Sedangkan Extraversion pada urutan berikutnya yang memengaruhi kreativitas. Dengan demikian, berhasil tidaknya anggota Dewan menyelesaikan suatu permasalahan dalam pekerjaan dengan menggunakan kreativitas, dipengaruhi oleh kepribadian, khususnya Extraversion, Agreeableness, dan Conscientiousness.

Satu hal penemuan dalam penelitian kali ini adalah bahwa kepribadian khususnya Big Five Personality berimplikasi terhadap kinerja, dengan memperhatikan pengaruh Kreativitas para anggota Dewan. Diskusi yang dapat disampaikan terkait hasil analisis tahap ke dua, bahwa hasil penelitian ini sesuai dengan penelitian Barrick, Piotrowski, dan Stewart (2002) yang membuktikan bahwa kepribadian akan berhubungan dengan kinerja khususnya pekerjaan atau tugas-tugas yang berkaitan dengan kognisi. Barrick juga mengemukakan, bahwa faktor Extraversion dan Conscientiousness lebih menggambarkan hasil apabila dikaitkan dengan Kinerja. Namun berbeda dengan penelitian Salgado (1996) yang mengemukakan bahwa Neuroticism juga dapat mempengaruhi Kinerja, walau kecil hasilnya. Hal ini dapat dimengerti, karena sedikit banyak dalam menyelesaikan suatu pekerjaan dipengaruhi oleh stabilitas emosi individu. Secara keseluruhan dari faktor Big Five Personality tersebut, mempengaruhi Kinerja (Hogan, 1996). Apabila diterapkan pada penelitian ini, yaitu penelitian dengan melihat pengaruh Big Five Personality terhadap kreativitas implikasinya terhadap Kinerja juga terbukti. Hasil analisis pengaruh Big Five Personality terhadap kreativitas dapat dijelaskan bahwa unsur kepribadian memiliki bukti yang cukup kuat sebagai pencetus kreativitas anggota Dewan.
Sedangkan terkait analisis tahap ke dua menggambarkan pengaruh kreativitas tidak begitu kuat untuk meningkatkan kinerja melalui deteksi kepribadian.

Dengan demikian, tuntutan terapan kreativitas terkait ide-ide, dan strategi capaian tujuan masing-masing komisi di DPRD dan partai yang mengusungnya, berdampak pada Kreativitas yang beragam antar anggota Dewan dalam pemecahan masalah. Hasil capaian kinerja anggota Dewan yang terdiri dari presensi kehadiran, layanan masyarakat, dan capaian target kinerja, secara langsung juga menggambarkan adanya pengaruh kreativitas.

\section{Kesimpulan}

Berdasarkan temuan penelitian, maka dapat disimpulkan sebagai berikut: (1) Ada pengaruh BigFive Personality terhadap kreativitas. Secara parsial Neuroticism dan Openness to Experience tidak berpengaruh terhadap kreativitas. Sehingga apabila hasil penelitian ini diterapkan pada kehidupan keseharian para anggota Dewan Kota 'S', tidak semua unsur kepribadian Big Five Personality anggota DPRD Kota 'S' berpengaruh terhadap kinerja. Extraversion, Agreeableness, dan Conscientiousness berpengaruh secara signifikan terhadap kreativitas, yang artinya anggota DPRD yang memiliki kecenderungan kepribadian Extraversion, Agreeableness, dan Conscientiousness yang baik akan dapat meningkatkan kreativitas, (2) Ada pengaruh masing-masing faktor dalam Big Five Personality yaitu faktor Neuroticism, Extraversion, Opennessto Experience, Agreeableness, dan Conscientiousness terhadap Kreativitas yang berimplikasi terhadap kinerja anggota Dewan. 
Saran

Berdasarkan hasil penelitian di atas, maka disarankan sebaiknya para anggota DPRD Kota 'S' selalu mengasah keterampilan dan kreativitasnya, sehingga dapat lebih meningkatkan Kinerjanya. Selain itu pada dasarnya para anggota DPRD Kota 'S' sudah memperlihatkan kemampuan yang optimal sesuai dengan kepribadian Big Five Personality yang terdiri dari faktor Neuroticism, Extraversion, Openness to Experience, Agreeableness, dan Conscientiousness. Akan tetapi perlu dilakukan tes psikologi agar dapat dideteksi calon legislatif yang memiliki kemampuan yang yang diharapkan akan mendukung kreativitas, Sehingga untuk meningkatkan Kinerja khususnya anggota DPRD Kota 'S', didapat calon anggota Dewan yang berkomitmen untuk melayani masyarakat sehingga ke depan tidak banyak anggota dewan yang meninggalkan Sidang Paripurna, maupun aktivitas lain yang berkaitan dengan tugas anggota Dewan.

\section{Kepustakaan}

Amelia. (2013). Anggota DPRD Wonosobo Terima Uang Proyek Dari Korban Penyekapan di Wonosobo.http://news. detik.com/read/2013/10/25/185341/239 5927/10/anggota-dprd-wonosoboterima-uang-proyek-dari-korbanpenyekapan-di-bekasi?r771108bcj.

Ardian, A. (2014). DPRD Bombana Hasilkan Sembilan Perda Selama 2013. Diunduh dari: http://www. ciputranews.com/politik/dprdbombana-hasilkan-sembilan-perdaselama-2013.

Askarian, N. (2013). “The Relationship Between Personality Traits and Job Performance" (Case Study: Employees of The Ministry of Education of Kerman. Interdiciplinary Journal of Con- temporary Research in Business, 5(8). Diunduh dari: Ijcrb.wels.com.

Baron, A. R., \& Jerald, G. (2000). Behaviorin Organization: Understanding \& Managing The Human Side of Work, Prentice Hall International Inc. Canada.

Barrick, M. R., \& Mount, M. K. (1991).“The Big Five Personality Dimensionsand Job Performance: A Meta-Analysis". Personal Psychology Journal, 44, 1-26.

Barrick, M. R., Piotrowski, M., \& Stewart, C. L. (2002). "Personality and Job Performance: Test of The Mediating Effect of Motivation Among Sales Representatives", Journal of Applied Psychology, 87(1), 43-51.

Berry, C.M., Ones,D.S., \& Sackett, P.R. (2007). "Interpersonal Deviance, Organizational Deviance, and Their Common Corelates ":A Review an Meta Analysis. Journal of Applied Psychology, 92,411-424.

Bramantyo. (2013). Selewengkan Anggaran, 18 Anggota DPRD Sragen Harus Diperiksa, Diunduh dari: http://jogja. okezone.com/read/2013/12/05/513/908 046/selewengkan-anggaran-18anggota-dprd-sragen-harusdiperiksa/large.

Buchanan, L.B., \& Roseanne, J., (1998). The Impact of Big Five personality Characteristics on Group Cohesion an Creativetask Performance.Desertation of Philosophy in Psychology. Blacksburg. Virginia.

Dessler, G. (1992). Manajemen Personalia, Diterjemahkan oleh: Agus Dharma. Edisi ketiga. Erlangga. Jakarta.

Dunnette, M. D., \& Hough, L. M. (1998). Handbook of Industrial and Organizational Psychology; Consulting Psychologists Press. Inc. Palo Alto. California.

Dunn, W. S., Mount, M. K., Barrick, M. R., 
\& Ones, D. S. (1995). "Relative Importanceof Personality and General Mental Ability in Manager 'Judgments of Applicant Qualifications", Journal of Applied Psychology, 4, 500-509.

Ferdinand, A. (2011) Metode Penelitian Manajemen. Badan Penerbit Universitas Diponegoro Semarang.

Ghozali, I. (2011). Aplikasi Analisis Multivariate Dengan Program IBM SPSS 19. Badan Penerbit UNDIP. Semarang.

Gatewood, R. D., Field, H. S., \& Barrick, M. (2011). Human Resource Selection $7^{\text {th }}$ Ed. South-Western. Cengage Learning. USA.

Goldberg, L. R. (1990). “An Alternative Description of Personality: The Big Five Factor Structure", Journal of Personality and Social Psychology, 59, 1216-1229.

Greer, C. R. (1995). Strategy and Human Resources, A General Managerial, Perspective. Prentice-Hall. Inc. New York.

Hakim, A. R., \& Lataruva, E. (2011). "Pengaruh kepribadian, Sikap, dan kepemimpinan terhadap Kinerja kreatif Dalam Organisasi"; Studi pada Organisasi kreatif di kota Semarang. Diunduh dari: http://eprints.undip. ac.id/28073/1/Jurnal.pdf.

Hogan, R., HoganJ., \& Robert, B.W. (1996). Personality Measurement E Employment Decision: Quest on and Answers. American Psychologist, 51(5), pp.467477.

Ivancevic, J. M. (2001). Human Resource Management, McGraw-HillCompanies, New York.

John, O. P. (1990). “The Big Five Factor Taxonomy: Dimension of Personality in The Natural Language \& in Questionaires". in L. Pervin (Ed.). Hand- book of Personality: Theory $\mathcal{E}$ Research. (pp 66-100). Guilford Press. New York.

Jauk,E., Mathios ,B.,Beate,D., and Aljoscha, C.N.", The relationship between Intelligence and Creativity; New Support for The Tresshold Hypothesis by Means ofEmpirical Breakpoint Detection. Journal of Intelligence. July 2013. 41(4):pp. 212-221.

Komaki, J. L., Coobs, T., Redding, T. P., \& Schepman, S. (2000)."A Rich and Rigorous Examination of Applied Behavior Analysis Research in The World of Work". International Review of Industrial and Organizational Psycho$\log y, 15,265-367$.

Kreitner, R., \& Angelo, K. (2001). Organizational Behavior. McGraw-Hill Companies. North America.

Lazarus, A. (2004). Reality Check: Is Your Behavior Aligned With Organizational Goal". Diunduh dari: http://www. findarticles.com/p/articles.

Lucius. (2013). Rapor Kinerja DPR Periode 2013 "Jeblok". Republika.Co.Id. Diunduh dari: http://www.republika.co.id/ berita/nasional/umum/13/11/20/mwjjy r-rapor-kinerja-dpr-periode-2013jeblok.

Media DPRD Kota Semarang. Edisi 01. (2013). Semarang .Edisi 02. (2013). Semarang . Edisi 03. (2013). Semarang . Edisi 04. (2013). Semarang

Pervin. L. A., \& Oliver P. J. (2000). Personality Theory \& Research. 8thedition. John Wiley \& Sons Inc. New York. p 256-271.

Pervin, L. A., Cervone, D., \& Oliver, P. J. (2012). Psikologi kepribadian: Teori dan Penelitian (edisi ke-9). Kencana Prenada Media Group. Jakarta. 
Ruky, A. (2002). Sistem Manajemen Kinerja. PT. Gramedia Pustaka Utama. Jakarta.

Saut, P.D. (2014). Penilaian Kinerja DPR Versi Formappi: Mayoritas Rapornya Sangat Buruk. DetikNews. Diunduh dari:

http://news.detik.com/read/2014/04/03 /130750/2544326/10/penilaian-kinerjadpr-versi-formappi-mayoritasrapornya-sangat-buruk

Sharpley, D. (1998). Personality Profiles, and The Dynamicsof High Performance. Diunduh dari: http://www.david. co.uk/Pagefiles/pp\%2022\%20. pdf

Salgado, J. F. (1997). “The Five Factor Model of Personality and Job Performance In The European Community", Journal of Applied Psychology, 82(1), 3043.

Simamora, H. (2005). Manajemen Sumber Daya Manusia. STIE YKPN. Yogyakarta.

Sonnentag, S. (2000). Expertise At Work: Experienceand Excellent Performance. International Review of Industrial and Organizational Psychology, 15, 223-264.

Staw, B. M. (1991). Psychologycal Demension of Organizational Behavior. Colliner Macmillan Canada Inc. New York.
Strenberg, R. J., \& Lubart T. I. (1999). Handbook of Creativity. UK: Cambridge University Press.

Supriadi. (2013). "Studi tentang Kinerja Pegawai Puskesmas kecamatan Sesayap Hilir Kabupaten Tana Tidung". E Jurnal Pemerintah Integratif, 1(3), 304$318 . \quad$ ISSN 2337-8670. ejournal.pin.or.id@Copyright. 2013.

Sugiyanto. (2008). Pengaruh Kepribadian, Kemampuan dan Motivasi Terhadap Kinerja. Diunduh dari: http://jurnal. utm.ac.id/index.php/ipi/article/view/15 $8 / 156$.

Sugiyono. (2003). Statistika Untuk penelitian. Penerbit: CV. Alfa Beta. Bandung.

Forum Masyarakat Peduli Parlemen Indonesia (Formappi). (2014). Penelitian: "83 Persen Anggota DPR Berkinerja Buruk". Tempo.Co. Diunduh dari: http://pemilu.tempo.co/read/news/201 4/04/03/269567571/Penelitian-83Persen-Anggota-DPR-BerkinerjaBuruk.

Wallace, A. R. ( 2010). The Art of Thought. LIPI Press. Jakarta.

Yoo, T. Y. (2002). A Meta-Analysis of The Big Five and Performance in Korea, Department of Psychology. Michigan State University. Michigan. 